\title{
Rapid selection of antimicrobial resistant bacteria in complex water systems by chlorine and pipe materials
}

Sadia Khan ${ }^{1,2^{*}}$ Tara K. Beattie ${ }^{1}$ and Charles W. Knapp ${ }^{1}$

1* Department of Civil and Environmental Engineering, University of Strathclyde, James Weir Building, 75 Montrose Street, Glasgow G1 1XJ, Scotland, United Kingdom

2 Department of Environmental Engineering, NED University of Engineering and Technology, University Road, Karachi-75270, Pakistan.

*Corresponding Author:

Tel.: $922199261261-8$, Ext: 2622

E-mail: sadiakhan@neduet.edu.pk

ORCID: Dr. Sadia Khan: 0000-0001-9377-6382 


\section{Abstract}

The presence of antimicrobial resistant bacteria and their genes in water supply system is an emerging issue. Resistant bacteria are difficult to treat and tend to horizontally transfer genes to other populations, including pathogens, thus complicating clinical treatments. However, the acute (short-term) response of bacteria to disinfection and exposure to various pipe materials remain unknown, and require investigation. Their responses to chlorination may mirror those of other microbial toxicants (e.g., subinhibitory antibiotics); as such, we test the hypothesis that pipe materials and the presence of chlorine could immediately stress bacteria and differentially select for antimicrobial resistant bacteria and biofilms.

Microcosm were created with polyvinylchloride, copper, and cement pipes, in which susceptible and resistant bacteria were competitively challenged to the presence of chlorination $(0.5 \mathrm{mg} / \mathrm{mL})$ over 5 days. Viable counts determined bacterial survival; while quantitative polymerase chain reaction was used to discern those with resistance genes. Physico-chemical parameters and chlorine levels monitored the environmental conditions to which the bacteria were exposed.

Results demonstrated that, in $56 \%$ of the cases, resistant bacteria became immediately enriched into biofilms due to chlorine exposure. In respects to pipe materials, greater proportion of resistant bacteria were found in biofilms on PVC and copper pipes, which represent common plumbing materials. The consequence is if bacteria contaminate drinking water systems, chemical conditions may immediately select for resistant strains, which could have unforeseen consequences in water safety.

\section{Key words}

biofilm; chlorine; disinfectant; water supply, antibiotic resistant bacteria 


\section{1. Introduction}

2 Antimicrobial resistance has emerged globally as an environmental problem, but it can cross

3 into being a food/water issue (e.g., Rusu, et al. 2015; Daghrir \& Drogui 2013). Water-

4 treatment plants and distribution systems use filtration and disinfection to control microorganisms and maintain the potability of water (Morente et al. 2013). While generally effective, bacteria (including those resistant) invade water systems via line disruptions or compromised cisterns, which introduce additional bacterial hazards. One cannot fully eradicate antimicrobial-resistant bacteria at normal treatment dosages; rather, much higher dosages often become required. Unfortunately, higher concentrations produce odour and taste problems and are difficult to achieve and maintain in water. While disinfectants help attenuate bacteria, nonetheless, they can selectively cause robust bacteria to proliferate (e.g., Aeromonas; McBain et al. 2004) and enrich antimicrobial-resistant bacteria.

The emergence, enrichment and transfer of resistance traits among bacteria depend on the microbial conditions in water distribution system. For example, biofilm-forming bacteria facilitate the attachment of microorganisms along the distribution system, and create community structures with greater complexity in terms of bacterial species than those in finished water (Chu et al. 2003), enhancing the capability to retain and protect pathogens. Furthermore, biofilm structures, with increased cell densities, facilitate the horizontal gene transfer of resistant genes. Moreover, bacterial physiology and metabolic rates vary along biofilm depth and reflect the gradients of nutrients versus chemical toxicants; the consequential reduced growth rates impacts biocide efficacy (Boe-Hansen et al. 2002). Protective layers of biofilm bacteria provide better tolerance to metal ions and other toxic substances, and improve survivability. Ultimately, biofilms in distribution systems become a generator and repository of resistance traits.

Conditions within water systems impact microorganisms and further contribute to the formation, composition, and proliferation of biofilms, e.g.: source water (Zeng et al. 2013), excretion of extracellular polymeric substances (Fish et al. 2015), physico-chemical conditions of water, hydraulic operations and flow rates (Douterelo et al. 2016), and composition of pipe materials (Nguyen et al. 2012).

Pipes comprise of various metals: galvanized iron, lead, copper, cast iron, steel (Nguyen et al. 2012); plastic materials: chlorinated polyvinyl chloride, polypropylene, polyethylene, polyvinylchloride and other materials: cementious composites, such as concrete (Niquette et al. 2000); and elasto-materials. Pipe materials and biofilms differentially affect 
each other; e.g., the presence of slime-forming bacteria facilitate metal tolerance, and biofilm bacteria produce organic acids, which contribute to the dissolution of metals and cement. Consequently, exposure to leached materials froms pipes can enhance antimicrobialresistance development, as frequently observed in contaminated enviornments in nature (e.g., Rodgers et al. 2018; Abdu et al. 2017). Ultimately, disinfection strategies and surface exposures may effectively attenuate most bacteria in distribution networks (e.g., Dong et al. 2018; Li et al. 2017), but could the stressors selectively contribute to resistance problem?

Here, we aimed to determine whether disinfectants and pipe material differentially affect bacteria with antimicrobial resistance. We employed experimental microcosms to examine how factors selectively influenced bacterial populations in a municipal water supply system, which included the formation of biofilms. These microcosms represented miniaturised analogues of actual distribution systems, and the bacteria were harvested from tap water; we hypothesized that different pipe material and disinfectant residuals impact microbial communities to select resistant bacteria and biofilm formation.

\section{Materials and methods}

\subsection{Microcosm set-up}

Experimental design involved laboratory microcosms with autoclaved phosphate buffer saline in Millipore water (10 mM, pH 7) having polyvinylchloride, copper and cement pipes (internal volume $102 \mathrm{~cm}^{3}$, surface area $240 \mathrm{~cm}^{2}$ ) versus presence/absence of free chlorine $(0.5 \mathrm{mg} / \mathrm{mL})$, as such six independent experiments were conducted. Peristaltic pumps (MP model M312) provided continuous recirculation (2 $\mathrm{mL} / \mathrm{min})$. Before each experiment, the microcosms, pipes and tubing were disinfected twice by $500 \mathrm{mg} / \mathrm{L}$ of sodium hypochlorite for 2 hours.

\subsection{Bacterial strains}

Bacillus, Paenibacillus, and Micrococcus were isolated from drinking water, except Bacillus subtilis R2 (the National Collection of Type Cultures, NCTC 10400, UK). The presence of antibiotic resistant genes (sul1 and sul2), mobile genetic elements (intI1) and chlorine susceptibility were determined as described previously (Khan et al. 2016a,b). The paired microcosm assays (chlorinated and chlorine free) were run with two populations of each genus having different level of resistance; sul1 (Bacillus and Paenibacillus), sul2 and intI1 (Micrococcus). 


\subsection{Experimental operation}

Overnight culture in 50-mL Luria-Bertani broth was centrifuged 3x (3000 rpm, $10 \mathrm{~min}$ ), washed with phosphate buffer saline, added (final concentration $1 \times 10^{5}$ cell/mL) to microcosms, and recirculated for five days at $20{ }^{\circ} \mathrm{C}( \pm 2)$, with 1-mL harvested from each pipe on days 0, 3 and 5 for viable counts (Nutrient Agar). Biofilm samples were taken on day 5 from $4-\mathrm{cm}^{2}$ area using sterile swabs; and $50-\mathrm{mL}$ water were filtered through $0.22 \mu \mathrm{m}$ membrane filter (Millipore, UK) on days 0 and 5. Filters and swabs were stored at $-20^{\circ} \mathrm{C}$. An additional $30-50-\mathrm{mL}$ were collected on days 3 and 5 to measure temperature, $\mathrm{pH}$ (Model S40 SevenMulti ${ }^{\mathrm{TM}}$, Mettler Toledo ${ }^{\mathrm{TM}}$ ), dissolved oxygen (DO 200 meter, VWR), total organic carbon (Teledyne Tekmar Apollo 9000 Combustion TOC Analyzer), and free chlorine (N, Ndiethyl-p-phenylenediamine colorimetric method, Hach).

\subsection{DNA extraction and quantitative polymerase chain reaction}

DNA were extracted using the ISOLATE II Genomic DNA kit (Bioline, UK) per manufacturer's instructions. Quantitative polymerase chain reaction (qPCR) were used to enumerate Bacillus (DeClerck, et al. 2004), Paenibacillus (Pettersson, et al. 1999), and Micrococcus species (Walcott and Gitaitis, 2000). qPCR involves the amplication (copying) of specific DNA sequences in a manner with timing of fluorescent detection to count the number of genes in a sample. Strains were discerned with primers associated with their antibiotic resistance genes (sul1, sul2; Pei et al. 2006) or mobile genetic element (intI1; Luo, et al. 2010); 16S-rRNA genes were quantified as a surrogate measure of 'total bacteria'. Serially diluted DNA standards $\left(10^{8}-10^{2}\right.$ genes $\left./ \mathrm{mL}\right)$ and a control without DNA template were run with each qPCR assay.

\subsection{Data Analyses}

From qPCR data, we calculated \%resistance [resistance genes]/[total genus] and bacterial abundances on pipe surfaces and water. Fold increases in total bacteria and \%resistance were calculated by comparing abundances between days 0 and 5. Abundances were logtransformed for presentation and statistical (e.g., normality) purposes. Data were analysed by Excel (Microsoft Office 2010) and MiniTab version 17.

\section{Results and discussion}

\subsection{Abundances of bacteria in biofilm}


Mirobial populations responded almost immediately by attaching to surfaces, with a greater percentage of those having resistant traits - suggesting that conditions in drinking water can select for bacterial contaminants with antimicrobial resistance. Surface swabs on day 5 for biofilm formation indicated that in $2 / 3$ of the cases bacteria adhereed themselves onto surfaces (Figure 1). Bacterial viability declines under stressful conditions, which resulted in difference in plate (viability) and genetic counts; however, the likely cause for declining gene counts in the water is the surface-attachment of cells, which would escape detection in the water. One exception was Bacillus, where only $35 \%$ of total bacteria and $65 \%$ of the resistant strain were found in biofilms in the polyvinylchloride microcosms. Further, only the resistant strains of Micrococcus and Paenibacillus were found on copper surfaces. Percentages of total and resistant populations were equivalent for other treatments.

Here, up to $10^{6.5} \mathrm{cfu} / \mathrm{cm}^{2}$ were found on surfaces in 5 days; more than reported previously (i.e., $10^{5} \mathrm{cfu} / \mathrm{cm}^{2}$; Frias et al. 2001). Bacteria showed different biofilm potentials Peanibacillus $>$ Bacillus $>$ Micrococcus (Figure 1) depending on pipe materials. Reported trend is as follow: polyvinylchloride < copper < steel < iron < cement < plastic (e.g. polyethylene) < elastomeric surfaces ( $\mathrm{Yu}$ et al. 2010), with some variation in adhesion potentials (Niquette et al. 2000). Different in this study, polyvinylchloride and copper pipes allowed more bacterial attachment with chlorine. Biofilm formation was faster on plastic pipes than copper pipes, due to copper toxicity (Yu et al. 2010); however in this experment, phosphate levels may have confounded effects of copper toxicity.

\subsection{Water-borne resistant and total populations}

Each pair of bacteria was added (totalling $2 \times 10^{5} \mathrm{cfu} / \mathrm{mL}, \log 5.3$ ) into the microcosms; heterotrophic plate counts determined viabilities (Table 1). In unchlorinated systems, viablecell counts declined by various orders of magnitude, except Micrococcus, which showed greater viability between days 3-5 in polyvinylchloride and copper pipes. Chlorination compromised viabilities by 1-2 orders greater reduction than untreated systems (Table 1). No viable Micrococcus were recovered from any chlorinated microcosm on day 3; although Paenibacillus and Micrococcus showed some recovery by day 5 in copper and polyvinylchloride pipes, respectively.

Both the susceptible and resistant strains were simultaneously challenged in the microcosms and monitored by quantitative PCR to differentiate strains. Their presence in water declined across all treatments (Table 2), except for Paenibacillus and Micrococcus spp. in the polyvinylchloride and cement treatments. In $44.4 \%$ of the cases, the resistant strains 
also declined, but at a lesser rate-resulting in mixed populations skewed towards a greater proportion of resistant bacteria.

Viability counts (Table 1) and gene detection (non-viable) are not analogous. Genetic (resistance and 16S-rRNA) traits indicate the presence of bacteria in the system; whereas plate counts indicate whether bacteria are capable of growing. Although not growing, their presence in the water (even with chlorine) could increase the prevelance of resistant genes if conditions change.

Low concentrations of disinfectants exert selection pressure on resistant populations, but other driving force i.e. pipe materials showed differential selection patterns in Micrococcus species (Table 1). Further, pipe materials impacted bacterial concentrations; e.g., polyvinylchloride pipes had greatest abundances of bacteria; and copper, the least, which may be attributed to its antimicrobial effects. Depending on the bacteria, resistant populations also proliferated in circulating water e.g., Micrococcus and Paenibacillus (Table 2).

\subsection{Water chemistry}

Water conditions remained similar: $3.3 \mathrm{mg} / \mathrm{L}$ dissolved oxygen $( \pm 0.7,95 \%$ confidence intervals); $87.4 \pm 58.4 \mathrm{mg} / \mathrm{L}$ total organic carbon; and initial chlorine $0.50 \mathrm{mg} / \mathrm{L}$, but declined to $0.15( \pm 0.06)$ and $0.06( \pm 0.03)$ on days 3 and 5, respectively. Initial pHs were $7.6( \pm 0.1)$; however, elevated $\mathrm{pHs}$ were observed in copper $(9.4 \pm 1.8)$ and cement microcosms $(9.0 \pm$ 1.3). Neither $\mathrm{pH}$ nor dissolved oxygen were impacted by inoculations or chlorination.

The dissolved oxygen and total organic carbon were within World Health Organization guidelines for drinking water. Dissolved oxygen influences corrosion in water pipes and bacterial activity, while the organic carbon increases chlorine demand and microbial growth. Here, any residual organic carbon likely reduced the free chlorine concentration as observed.

\subsection{Relationship between physicochemical properties, abundances of genes, and}

\section{bacteria}

Comparision of population abundances and viabilities to the physico-chemical conditions (Table 3) indicated that dissolved oxygen increased bacterial abudances, and might have an inverse impact on relative abundance of resistant strains (though significant in Paenibacillus assays only). Occasional correlations occurred between organic carbon and bacterial abundances. Further, elevated $\mathrm{pH}$ reduced total bacteria, which were observed by inverse correlations in absolute abundances, and positive corrlations in relative numbers - suggesting that presence of resistant strains were less impacted. There were no significant correlations 
between viable counts and resistant gene abundances, nor chlorine and resistant genes; while interesting, this does not surprise as gene presence does not represent viability, as discussed previously.

\section{Conclusion}

This study demonstrated the factors affecting the fate of antimicrobial resistance in waterdistribution systems; pipe material, residual disinfectant, and water age shift community dynamics. Resistant bacteria developed biofilm on polyvinylchloride and copper pipes (66.7\%) more than cement pipes (16.7\%). Biofilm-forming bacteria behave differently than planktonic cells, and due to physiological adaptations, they exhibit greater resistance to disinfectants as $55.6 \%$ cases showed more resistant population in biofilm in the presence of chlorine. In term of total population more bacteria were in biofilm $10^{6.5} \mathrm{cfu} / \mathrm{mL}$. Further, increased population densities and selective pressures by sub-inhibitory concentrations of disinfectants and pipes create conditions, underwhich microorganisms acquire new traits and become more resistant.

\section{Acknowledgement}

The research is supported by Schlumberger Foundation's Faculty for the Future in the form of funding for SK's $\mathrm{PhD}$.

\section{References}

Abdu N, Abdullahi AA, Abdulkadir A (2017) Heavy metals and soil microbes. Environ Chem Lett 15(1): 65-84. doi:10.1007/s10311-016-0587-x

Boe-Hansen R, Albrechtsen H-J, Arvin E, Jorgensen C (2002) Bulk water phase and biofilm growth in drinking water at low nutrient conditions. Water Res 36: 4477-4486.

Chu C, Lu C, Lee C, Tsai C (2003) Effects of chlorine level on the growth of biofilm in water pipes. J Environ Sci Health Part A, 38(7): 1377-1388. doi:10.1081/ese-120021132

Daghrir R, Drogui P (2013) Tetracycline antibiotics in the environment: a review. Environ Chem Lett. 11(3): 209-227. doi.org/10.1007/s1031-013-0404-8

DeClerck E, Van Mol K, Jannes G, Rossau R, De Vos P (2004) Design of a 5' exonuclease-based real-time PCR assay for simultaneous detection of Bacillus licheniformis, members of the 'B. cereus group' and B. fumarioli in gelatine. Lett Appl Microbiol 39 (1):109-115. doi:10.1111/j.1472-765X.2004.01550.x

Dong F, Li C, Lin Q, Duan H (2018) Effect of pipe materials on disinfection by-products and bacterial communities during sulfamethazine chlorination in a pilot-scale water distribution system. Environ Chem Lett. doi:10.1007/s10311-018-00823-3 
Douterelo I, Jackson M, Solomon C, Boxall J (2016) Microbial analysis of in situ biofilm formation in drinking water distribution systems: implications for monitoring and control of drinking water quality. Appl Microbiol Biotechnol 100(7): 3301-3311. doi:10.1007/s00253-015-7155-3

Fish KE, Collins R, Green NH, Sharpe RL, Douterelo I, Osborn AM, Boxall JB (2015) Characterisation of the physical composition and microbial community structure of biofilms within a model full-scale drinking water distribution system. PLoSOne 10(2): e0115824. doi:10.1371/journal.pone.0115824

Frias J, Ribas F, Lucena F (2001) Effects of different nutrients on bacterial growth in a pilot $\begin{array}{lllll}\text { distribution } & \text { system. }\end{array}$ https://doi.org/10.1023/A:1012229503589

Khan S, Beattie TK, Knapp CW (2016a) Relationship between antibiotic- and disinfectant-resistance profiles in bacteria harvested from tap water. Chemosphere 152: 132-141. doi:10.1016/j.chemosphere.2016.02.086

Khan S, Knapp CW, Beattie TK (2016b) Antibiotic resistant bacteria found in municipal drinking water. Environ Process 3: 541-552. doi:10.1007/s40710-016-0149-Z

Li C, Feilong D, Feng L, Zhao J, Zhang T, Cizmas L, Sharma VK (2017) Bacterial community structure and microorganism inactivation following water treatment with ferrate(VI) or chlorine. Environ Chem Lett 15(3): 525-530

Luo Y, Mao D, Rysz M, Zhou Q, Zhang H, Xu L, Alvarez PJJ (2010) Trends in antibiotic resistance genes occurrence in the Haihe River, China. Environ Sci Technol 44 (19):7220-7225. doi:DOI: $10.1021 / \mathrm{es} 100233 \mathrm{w}$

McBain AJ, Ledder RG, Moore LE, Catrenich CE, Gilbert P (2004) Effects of quaternaryammonium-based formulations on bacterial community dynamics and antimicrobial susceptibility. Appl Environ Microbiol 70(6), 3449-3456. doi:10.1128/AEM. 70.6.34493456.2004

Morente OE, Fernandez-Fuentes MA, Grande Burgos MJ, Abriouel H, Perez Pulido R, Galvez A (2013) Biocide tolerance in bacteria. Int J Food Microbiol 162(1): 13-25. doi:10.1016/j.ijfoodmicro.2012.12.028

Nguyen C, Elfland C, Edwards M (2012) Impact of advanced water conservation features and new copper pipe on rapid chloramine decay and microbial regrowth. Water Res 46(3): 611-621. doi:10.1016/j.watres.2011.11.006

Niquette P, Servails P, Savoir R (2000) Impacts of pipe materials on densitites of fixed bacterial biomass in a drinking water distribution system. Water Res 34(6): 1952-1956. DOI: 10.1016/S0043-1354(99)00307-3

Pei R, Kim S-C, Carlson KH, Pruden A (2006) Effect of river landscape on the sediment concentrations of antibiotics and corresponding antibiotic resistance genes (ARG). Water Research 40 (12):2427-2435. doi:10.1016/j.watres.2006.04.017 
Pettersson B, Rippere KE, Yousten AA, Priest FG (1999) Transfer of Bacillus lentimorbus and Bacillus popilliae to the genus Paenibacillus with emended descriptions of Paenibacillus lentirnorbus comb. nov. and Paenibacillus popilliae comb. nov. Int J Sys Bacteriol 49 (531540)

Rodgers K, McLellan I, Peshkur T, Williams R, Tonner R, Hursthouse AS, Knapp CW, Henriquez FL (2018) Can the legacy of industrial pollution influence antimicrobial resistance in estuarine sediments? Environ Chem Lett. doi.org/10.1007/s10311-018-0791-y

Rusu A, Hancu G, Uivaroşi V (2015) Fluoroquinolone pollution of food, water and soil, and bacterial resistance. Environ Chem Lett 13: 21. doi.org/10.1007/s10311-014-0481-3

Walcott RR, Gitaitis RD (2000) Detection of Acidovorax avenae subsp. citrulli in watermelon seed using immunomagnetic separation and the polymerase chain reaction. Plant Disease 84 (4):470-474. http://dx.doi.org/10.1094/PDIS.2000.84.4.470

Yu J, Kim D, Lee T (2010) Microbial diversity in biofilms on water distribution pipes of different materials. Water Sci Technol 61(1): 163-171. doi:10.2166/wst.2010.813

Zeng DN, Fan ZY, Chi L, Wang X, Qu WD, Quan ZX (2013) Analysis of the bacterial communities associated with different drinking water treatment processes. World J Microbiol Biotechnol 29(9): 1573-1584. doi:10.1007/s11274-013-1321-5 

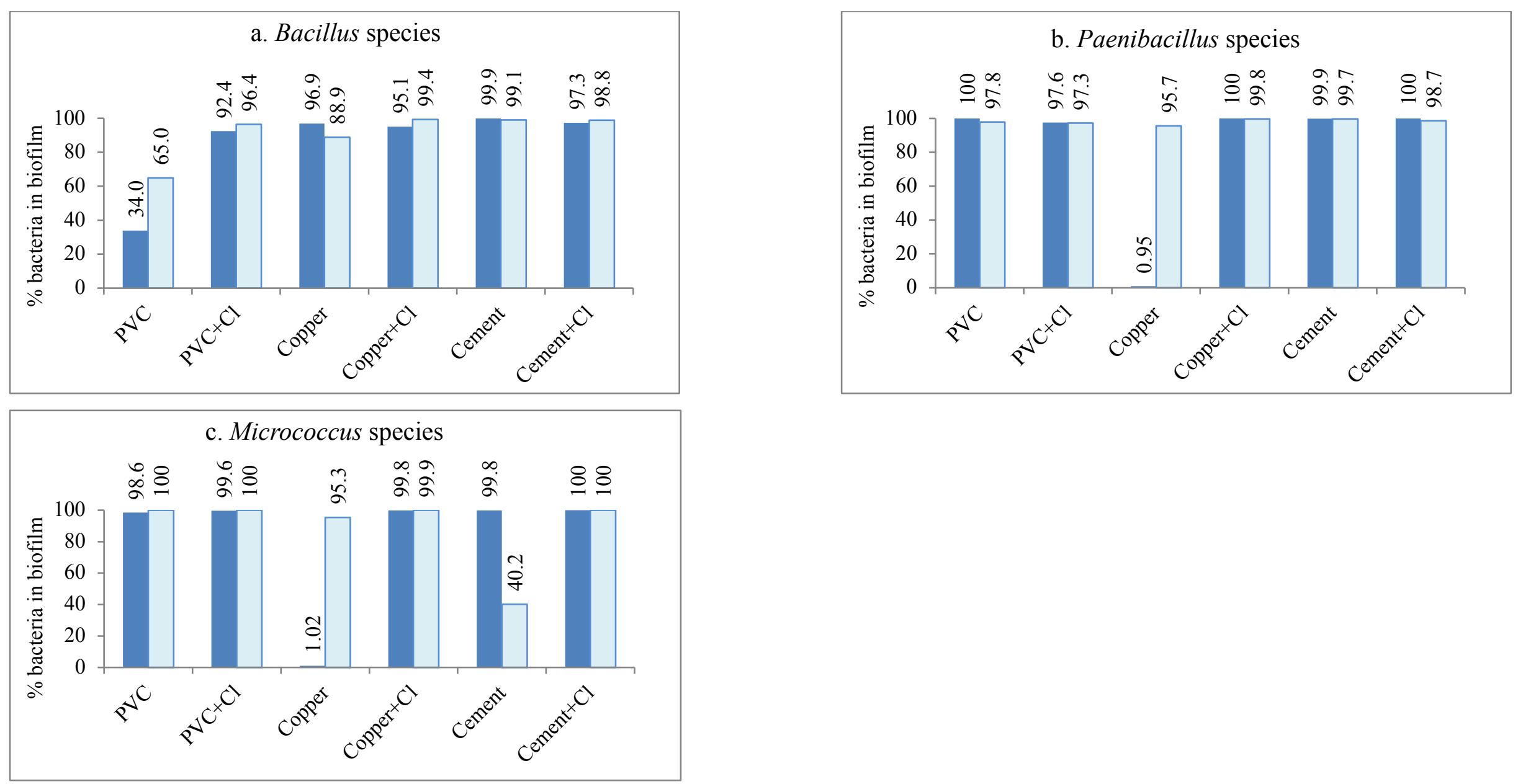

Figure 1. Percentage of bacteria attached to surfaces after 5 days. Chlorination selection was found in resistant bacteria (Bacillus R1 and Paenibacillus R), which were higher in chlorinated pipes than non-chlorinated in all cases. $\mathrm{Cl}=$ chlorinated, $\mathrm{PVC}=$ polyvinylchloride. : $\square$ Total bacteria Resistant bacteria 
Table 1. Heterotrophic Plate Count $(\log \mathrm{cfu} / \mathrm{mL})$ in the different pipe material in the absence and presence of $0.5 \mathrm{mg} / \mathrm{L}$ free chlorine; each species was added on Day 0 at a concentration of $10^{5} \mathrm{cfu} / \mathrm{mL}(\log$ total bacteria $=5.3)$. cfu colony forming units, ND not detected

\begin{tabular}{lcc|cc|cc}
\hline \multirow{2}{*}{ Treatment } & \multicolumn{2}{c|}{ Bacillus } & \multicolumn{2}{c|}{ Paenibacillus } & \multicolumn{2}{c}{ Micrococcus } \\
\cline { 2 - 7 } & Day-3 & Day-5 & Day-3 & Day-5 & Day-3 & Day-5 \\
\hline Polyvinyl chloride & 2.9 & 2.0 & 3.2 & 1.5 & 1.6 & 2.8 \\
Polyvinyl chloride+Chlorine & ND & ND & 1.2 & 0.5 & ND & 1.9 \\
\hline Copper & 2.8 & 1.2 & 3.3 & 2.0 & 0.9 & 2.8 \\
Copper+Chlorine & 0.3 & ND & 1.2 & 1.7 & ND & ND \\
\hline Cement & 2.9 & 2.6 & 3.5 & 2.4 & 3.5 & 3.0 \\
Cement+Chlorine & ND & ND & 1.4 & 0.7 & ND & ND \\
\hline
\end{tabular}

Table 2. Changes in total and resistant bacterial abundances after 5 days in microcosms as determined by polymerase chain reaction. + increase, - decrease, 0 unchanged, $\mathrm{ND}=$ not detected, $\mathrm{Cl}=$ chlorine, $\mathrm{PVC}=$ polyvinylchloride.

\begin{tabular}{|c|c|c|c|c|c|c|c|}
\hline Assay & Organism Туре & PVC & $\begin{array}{l}\text { PVC } \\
+\mathrm{Cl} \\
\end{array}$ & Copper & $\begin{array}{c}\text { Copper } \\
+\mathrm{Cl} \\
\end{array}$ & Cement & $\begin{array}{c}\text { Cement } \\
+\mathrm{Cl} \\
\end{array}$ \\
\hline \multirow{2}{*}{ Bacillus } & Total Bacillus & - & - & - & - & - & - \\
\hline & $\%$ Resistant & - & - & + & - & - & - \\
\hline \multirow{2}{*}{ Paenibacillus } & Total Paenibacillus & ND & + & - & - & - & ND \\
\hline & $\%$ Resistant & + & + & 0 & - & - & 0 \\
\hline \multirow{2}{*}{ Micrococcus } & Total Micrococcus & - & - & - & - & ND & ND \\
\hline & \% Resistant & + & - & + & + & + & - \\
\hline
\end{tabular}


Table 3. Pearson correlation analysis between physicochemical properties and bacterial abundances. Significant limit was $p<0.10 . \mathrm{DO}=$ dissolved oxygen, $\mathrm{TOC}=$ total organic carbon, $\mathrm{Cl}=$ chlorine, $\mathrm{HPC}=$ heterotrophic plate count $(\log$ transformed).

\begin{tabular}{|c|c|c|c|c|c|c|c|c|c|c|c|c|}
\hline \multirow{2}{*}{ Assay } & \multirow{2}{*}{ Genes } & \multirow{2}{*}{$\begin{array}{c}\text { Pearson } \\
\text { correlation }\end{array}$} & \multicolumn{5}{|c|}{ Water } & \multicolumn{5}{|c|}{ Biofilm } \\
\hline & & & DO & TOC & Cl & pH & HPC & DO & TOC & Cl & pH & HPC \\
\hline \multirow{4}{*}{ Bacillus } & \multirow{2}{*}{$\begin{array}{c}\text { Bacillus } \mathrm{R} 1 / \text { total } \\
\text { bacteria }\end{array}$} & $r=$ value & -0.17 & 0.03 & -0.60 & 0.54 & 0.28 & 0.43 & -0.50 & -0.59 & 0.95 & -0.23 \\
\hline & & $p$ value & 0.69 & 0.95 & 0.12 & 0.17 & 0.51 & 0.39 & 0.31 & 0.91 & 0.00 & 0.66 \\
\hline & \multirow{2}{*}{ Total bacteria } & $r=$ value & 0.63 & -0.23 & 0.32 & -0.55 & 0.20 & -0.39 & -0.00 & 0.29 & -0.67 & 0.38 \\
\hline & & $p$ value & 0.10 & 0.59 & 0.44 & 0.15 & 0.63 & 0.45 & 0.99 & 0.58 & 0.14 & 0.46 \\
\hline \multirow{4}{*}{ Paenibacillus } & \multirow{2}{*}{$\begin{array}{l}\text { Paenibacillus R/ } \\
\text { total bacteria }\end{array}$} & $r=$ value & -0.89 & 0.78 & 0.01 & 0.82 & -0.10 & -0.10 & 0.15 & 0.34 & 0.43 & 0.33 \\
\hline & & $p$ value & 0.02 & 0.07 & 0.95 & 0.05 & 0.33 & 0.87 & 0.81 & 0.57 & 0.47 & 0.59 \\
\hline & \multirow{2}{*}{ Total bacteria } & $r=$ value & 0.88 & -0.78 & -0.04 & -0.81 & 0.06 & -0.09 & -0.12 & -0.51 & -0.35 & -0.19 \\
\hline & & $p$ value & 0.02 & $\mathbf{0 . 0 7}$ & 0.94 & 0.05 & 0.92 & 0.89 & 0.84 & 0.38 & 0.57 & 0.76 \\
\hline \multirow{4}{*}{ Micrococcus } & \multirow{2}{*}{$\begin{array}{l}\text { Micrococcus } \mathrm{S} / \\
\text { total bacteria }\end{array}$} & $r=$ value & -0.31 & 0.33 & -0.17 & 0.85 & -0.23 & 0.63 & 0.31 & 0.01 & -0.32 & -0.42 \\
\hline & & $p$ value & 0.50 & 0.43 & 0.72 & 0.02 & 0.62 & 0.18 & 0.55 & 0.99 & 0.54 & 0.71 \\
\hline & \multirow{2}{*}{ Total bacteria } & $r=$ value & 0.46 & -0.30 & 0.20 & -0.88 & 0.12 & 0.05 & -0.82 & 0.72 & -0.47 & -0.53 \\
\hline & & $p$ value & 0.29 & 0.51 & 0.67 & 0.01 & 0.80 & 0.93 & 0.04 & 0.11 & 0.35 & 0.28 \\
\hline
\end{tabular}

